\title{
Forum
}

\section{How Heterodox is the Mainstream? Economic Theory and Economic Policy Advice in the English-speaking Area Survey by the journal INTERVENTION}

At the beginning of December 2006, Intervention asked its Scientific Board and the authors of previous issues for their views on the relationship of heterodox economic theory to the mainstream of economics. We asked those who are living and working in the English-speaking area to relate their assessment to this area. Board members and authors in German-speaking countries were requested to assess the situation there. The submitted answers are printed below starting with the contributions concerning the English-speaking area (in English) and followed by the contributions concerning the German-speaking area (in German) on page I2.

This survey was stimulated by studies showing only a limited consensus in matters of economic policy and theory within the so-called mainstream. A comparative evaluation of a recent and of earlier surveys of the American Economic Association (Fuller/Geide-Stevensen 2003) shows a relatively high degree of consensus concerning international economics free trade is widely preferred. With respect to micro- and macro-economics, however, the opinions reveal a decreasing degree of homogeneity. The general equilibrium model still dominates in micro-economics but scepticism concerning the applicability of this conception is on the rise. In the realm of macro-economics, statements based on monetarist as well as New Keynesian or supply-side views are met with approval. Thus, for example, both the view that fiscal impulses are effective in a situation of under-employment and that the primary cause of inflation is a too strong growth in money supply are accepted. In the course of time, however, an erosion of approval of Keynesian positions can be observed.

However, these results derived from the US-American experience cannot be transferred one-to-one to the situation in other countries. Frey et al. (1984) identify country-specific traditions concerning general economic attitudes. In the USA, Germany, and Switzerland economists tend to prefer free markets, whereas in Austria and France an interventionist weltanschauung prevails.

Which conclusions can be drawn from these results? Is the widespread belief of a uniform and dominating mainstream a misconception? Is economics more pluralistic and heterogeneous than commonly thought? And if so, does this imply that the mainstream is more heterodox in terms of a general understanding of the economy which takes into account the historical and societal conditions of economic processes and for which plurality of approaches is the key to the analysis of the economy? The answers of some members of our Scientific Board and of some authors of previous volumes offer a first assessment.

The survey was conducted by Torsten Niechoj 
Question I: Heterodox thinking is virtually defined in contrast to orthodoxy, i. e. the hegemonic thinking. Nevertheless, unconventional positions and approaches expand repeatedly into teaching and research which might indicate that the economic mainstream is more complex and diversified as usually assumed. How heterodox is the mainstream in the English-speaking area in your opinion?

There are important differences between orthodox and non-orthodox economics in the English-speaking area. The assumptions made and the methodologies employed do differ substantially. In some cases each side might accuse the other side that they do not understand economics! But there are open-minded economists in both camps that attempt to understand the reconomics of the other sider. I do believe this is very healthy and should be encouraged all the time. Understanding the assumptions and the methodologies employed, and pursuing healthy discussions to appreciate the position of each other can only be a great way forward.

Philip Arestis, University of Cambridge, $U K$

As a geographer, I have drawn on a variety of disciplines and disciplinary traditions throughout the social sciences to address economic problems. From this perspective, I have found a wide range of positions. In fact, considering the contributions of economic geography, economic sociology, etc. the perceived ১orthodoxy` of economics appears to be the more unconventional approach. Harald Bauder, University of Guelph, Canada

Mainstream used to be Keynesian theory until early I970s. Various ways of incorporating effective demand through the intellectual tradition of Kalecki and Keynes still provide the basis of heterodoxy. On distribution and price theory, the counter to mainstream demandsupply approach à la partial or general equilibrium is provided by the capital theory critique of Sraffa. Heterodoxy still has to find a commonly accepted way as to how to bring these two streams together. Amit Bhaduri, University of Pavia, Italy, and Council for Social Development, New Delhi, India

Not very diversified.

Not heterodox at all.
Stefan Collignon, London School of Economics, UK

Paul Davidson, New School For Social Research, and Editor of the Journal of Post Keynesian Economics

There may certainly be key methodological, theoretical and policy differences between mainstream and non-mainstream economics, but often the analysis of these differences is historically dated or non-scientific (e.g. based on personal views). However, I am optimistic that things are slowly changing. For instance, in recent times there has been a very healthy analysis of the similarities and differences between the New Consensus view in mainstream economics and the non-mainstream Post Keynesian view of macroeconomics.

Giuseppe Fontana, University of Leeds, UK, and University of Sannio, Italy

When I define mainstream economics I do so solely in terms of theory. Hence in the US and UK main-stream economics in terms of theory is homogeneous and it is dominant. Of course there are different theoretical views within the mainstream but those differences 
are very small - like differences between Baptists and Methodists. Arguments are being made that there are great differences in mainstream economics and some of the differences verge on being heterodox, but these are mostly claims without substantive evidence; and the comparisons being made are like comparing Lutherans and Catholics as oppose to comparing Lutherans to secularists/non-believers/atheists. In terms of policy, I do not really care what mainstream economists propose since they always propose something that involves markets and hence pro-capitalism. Since I would like to do away with capitalism, I view their policies as relatively homogeneous.

Frederic S. Lee, University of Missouri-Kansas City, USA

Many themes in the mainstream do follow parallel general problems to the heterodox, but usually without the theory of the heterodox; e.g., public goods, externalities, trust, institutions, etc. In some areas there is some convergence. The main differences are that: (a) most orthodox perspectives do not assume (as heterodoxy does) that externality-type effects are rampant - they are often assumed to be special cases; (b) most of the mainstream is economically libertarian whereas heterodoxy is mainly socially libertarian; (c) most orthodoxies are based more on the theory of competitive markets, small number of externalities and high costs of government; whereas they should be more empirically based on degrees of monopoly, high levels of system functions and lower costs of government (heterodoxy); and (d) most orthodoxies inadequately include radical uncertainty, capitalism as a system, the disembedded economy, the economic surplus/surplus value; the enabling effect of institutions; the need for participatory democracy in firms, families and other institutions; instrumentalceremonial functions of institutions; the way in capitalism destroys the environment, sociality, families, communities in the very process of creation (they underrate the destructive elements or ignore the endogenous linkages between destructive creation). (e) Orthodoxy also tends to be more based on mechanical prediction rather than understanding and evolutionary (and wave like) prediction.

Phillip Anthony O'Hara, Curtin University of Technology, Perth, Australia

Question 2: Neoclassical micro-economics still plays a crucial role for the academic mainstream. Furthermore, formalised models or technically elaborated empiricall econometric studies are the conditio sine qua non to publish in most of the top journals. What distinguishes heterodox from orthodox thinking in respect to the methodical approach? Or is there no such difference?

Here I think non-orthodox thinking has suffered rather dramatically by not adopting what we might call a formal and empirical approach. The little that has been applied has been very successful so far in exposing pitfalls in the relevant orthodox methodological approach. Furthermore such an approach would clearly imply that non-orthodox economists can have a meaningful dialogue with orthodox economists to the advantage of economics in more general terms.

Philip Arestis, University of Cambridge, UK

To me, the scritical engagement with economic processes is more fruitful than a neoclassical perspective. Part of this critical engagement entails taking the social and discursive 
construction of the economic seriously, acknowledging historical and geographical particularities and engaging in critical and dialectical reasoning.

Harald Bauder, University of Guelph, Canada

Neo-classical theory fails to distinguish between micro and macro theory, as both are based on the assumption of maximization. Game theory introduced some variation by allowing for strategic interdependence among rational players still trying to maximize taking into account interdependence. The fact that macro theory is based on structural rather than strategic interdependence, and shown up by accounting identities/equations like that between investment and saving, or current account deficit equals capital account surplus, is little understood in the US-style macroeconomic theorising. The result is a failure to highlight various fallacies of composition inherent in the market system as the distinguishing feature of macro theory, e.g. paradox of thrift, money wage cut, downsizing by corporations, different ways of linking capital and current account of the balance of payments etc.

Amit Bhaduri, University of Pavia, Italy, and Council for Social Development, New Delhi, India

There is no such distinction for theory. Only bad economics versus professional economics.

Stefan Collignon, London School of Economics, UK

Heterodox should not adopt General Equilibrium models as the General Theory micro foundations of economics. Mainstream theories do.

Paul Davidson, New School For Social Research, USA, and Editor of the Journal of Post Keynesian Economics

A heterodox approach totally rejects mainstream methodology. I argue that heterodox methodology is grounded in critical realism and the method of grounded theory. Of course econometrics and empirically grounded mathematical models can be used, but this is quite different from mainstream methodology.

Frederic S. Lee, University of Missouri-Kansas City, USA

The main differences are that orthodoxy tends not to use the following aspects of heterodoxy: I. Holism, circular and cumulative causation and interdisciplinary analysis; 2. participatory observation, case studies, and detailed institutional scrutiny; 3 . heterogeneous group analysis - gender, class, ethnicity and species - as well as endogenous preferences, etc. of agents; 4. positive and normative analysis; 5. examining the deeper layers of socioeconomic reproduction. Phillip Anthony O'Hara, Curtin University of Technology, Perth, Australia

Question 3: Academic research is one side of a coin; economic policy and political practice are the other side. To what extent is heterodox thinking able to influence political practice in your opinion? What are the strengths and what the weaknesses of heterodox economic policy advice, and how could heterodox economists increase their influence as economic advisors?

Interaction with economists of different persuasions in a way that avoids phobia of tools which others believe to be paramount in economics, can help greatly in more general terms but also in terms of economic advice. Economic policy and political practice require more of 
a multidisciplinary approach, which can be provided more persuasively by the non-orthodox camp. Yet advice from the non-orthodox camp is not always sought! This is where I believe that if the non-orthodox economists were to adopt more positively what I suggested under (I) and (2) above, non-orthodox thinking can become more acceptable and, thus, more influential to economic policy and political practice. Philip Arestis, University of Cambridge, UK

Important institutions, such as labour unions, that traditionally permitted knowledge transfer form academia to public policy have been under attack. A shift towards university education and newly emerging international institutions and movements may become increasingly important. Harald Bauder, University of Guelph, Canada

What is the most fruitful way of economic theorising is not decided either by logical rigour (recall capital theory controversy) or even by the effectiveness of policies (the current unemployment problem of Western Europe). It is shaped by dominant interests, and prizes, recognitions come mostly by serving those interests through theoretical justifications. Given the dominance of global finance capital and of the corporations, neoclassical theory is adapting itself to serve those interests. Heterodox policies have little acceptability in that context. It has a better chance in some Latin American countries.

Amit Bhaduri, University of Pavia, Italy, and Council for Social Development, New Delhi, India

There is more scope on the left for heterodox influence. The problem is that heterodox theories are not well proven and therefore do not easily get accepted by government policy makers in bureaucracies.

Stefan Collignon, London School of Economics, UK

Mainstream advice is always bad advice since it requires theoretical foundations that are incompatible with a money using, market oriented entrepreneurial economy.

Paul Davidson, New School For Social Research, USA, and Editor of the Journal of Post Keynesian Economics

Many friends have recently taken the view that academic research does not have much influence on economic policy and political practice. I think differently, but I do agree that if you take that view then the divide between mainstream and non-mainstream economics became irrelevant as long as the economic advice works.

Giuseppe Fontana, University of Leeds, UK, and University of Sannio, Italy

Heterodox economic policy that is based on heterodox economic theory is really unable to influence economic policy in the US/UK. First the policy makers only know mainstream economics/policy and hence follow it. In addition, many heterodox policies would undermine the power and control of capitalists and hence be rejected outright. If heterodox economists want to have more influence in economic policy they must teach more undergraduate students heterodox economics and then wait 20 years for those students to gain political positions that determine economic policy. Heterodox economists are generally outsiders and hence have very little influence - if heterodox economists want to have influence then they should become pro-capitalists. Personally I am not willing to sell my soul to gain some political/economic influence. Of course there is another way for heterodox economists to 
gain some influence as economic advisors - back minor political parties and hope that they become more powerful over time - Green Party in the US/UK is one possibility or even some Marxist political parties. The strength or weaknesses of heterodox economic advice it depends on the advice being given. In my view the kind of economic advice I would offer has only strengths and no weaknesses since it is advice that is designed to help the poor and disadvantage members of society. However, my advice would be rejected because it would offend the powers that be. This is not a weakness of the advice, but just the current state of affairs.

Frederic S. Lee, University of Missouri-Kansas City, USA

Strengths: I. Pragmatic; 2 . based on realism; 3. balanced; 4 . socially relevant in the long run; 5. comprehensible; 6. community-based. Weaknesses: I. complex; 2. dependent upon much knowledge; 3. dependent upon community feedback. How could heterodoxy enhance their policy influence? I. Spending more time on linking theory and policy; 2. spend more time writing on the critical problems of the world; 3 . link policy with more communication among policy-makers and the community; 4 . be elected to parliament, join businesses and real world institutions.

Phillip Anthony O'Hara, Curtin University of Technology,

Perth, Australia

\section{References}

Frey, Bruno S./ Pommerehne, Werner W./Schneider, Friedrich/Gilbert, Guy (1984): Consensus and Dissension among Economists: An Empirical Inquiry, in: American Economic Review, Vol. 74, No. 5, pp. 986-994

Fuller, Dan/Geide-Stevenson, Doris (2003): Consensus Among Economists: Revisited, in: Journal of Economic Education, Vol. 34, No. 4, pp. 369-387

\section{Wie heterodox ist der Mainstream? Ökonomische Forschung und wirtschaftspolitische Beratung im deutschsprachigen Raum Umfrage der Zeitschrift INTERVENTION}

Anfang Dezember 2006 befragte InTERvention den Beirat der Zeitschrift sowie die Autor|inn|en bisheriger Hefte, wie sie das Verhältnis von heterodoxer ökonomischer Theorie zum Mainstream der Wirtschaftswissenschaften einschätzen. Die im deutschsprachigen Raum Lebenden und Arbeitenden haben wir gebeten, sich auf diesen zu beziehen. Alle anderen waren aufgefordert, das Heterodoxie-Mainstream-Verhältnis für den englischsprachigen Raum zu beurteilen. Die eingegangenen Antworten für den deutschsprachigen Raum haben wir nachfolgend abgedruckt, die Antworten zum englischsprachigen Raum finden Sie auf den voranstehenden Seiten (in englischer Sprache). 